The performance of group-affiliated firms during institutional transition: A longitudinal study of Indian firms

\author{
Alessandro Zattoni \\ Management Department, Parthenope University \& \\ SDA Bocconi School of Management, Strategic and Entrepreneurial Management \\ Department, Via Bocconi 8, 20136 Milano. Tel: +39-02-5836-2527; Fax: +39-02-5836- \\ 2530; E-mail: alessandro.zattoni@unibocconi.it
}

Torben Pedersen

Copenhagen Business School

tp.smg@cbs.dk

Vikas Kumar

Bocconi University

vikas.kumar@unibocconi.it 


\title{
The performance of group-affiliated firms during institutional transition: A longitudinal study of Indian firms
}

\begin{abstract}
Manuscript Type: Empirical

Research Question/Issue: Institutional and transaction cost theories highlight the idea that group-affiliated firms outperform unaffiliated firms in emerging economies. However, the persistence of superior performance among group-affiliated firms could be challenged by the recent, quick development of markets and institutions in these countries. This article explores the link between firm performance and the evolution of the institutional environment.
\end{abstract}

Research Findings/Insights: We analyze how business group affiliation affected firm performance in India in the post-reform era, i.e. from 1990 to 2006. Our findings show that: (i) the performance benefits of group affiliation are evident in the early phase of institutional transition but level out in the late phase; (ii) older group-affiliated firms are better able to cope with institutional transition than younger group-affiliated firms; and (iii) group-affiliated service firms are better able to cope with institutional transition than group-affiliated manufacturing firms.

Theoretical/Academic Implications: Our findings support both the institutional and transaction cost theories of business groups, and extend them by adding a two-phase longitudinal component. The findings also highlight the fact that the benefits of group membership vary for different firms in the group, which is in line with other recent studies.

Practitioner/Policy Implications: The article has implications for managers and policy makers. Managers of business groups should adapt the timing of strategies to the evolution of the institutional environment. Policy makers should focus on the consequences of their policies, as they may undermine the efficiency of large national companies.

Keywords: Corporate Governance; Business Groups; India 


\section{The performance of group-affiliated firms during institutional transition: A longitudinal study of Indian firms}

\section{INTRODUCTION}

Business groups are the dominant organizational form in emerging economies. A business group consists of individual firms with multiple links through which the firms are coordinated in order to achieve common goals (Granovetter, 1994; Leff, 1978; Strachan, 1976). Although business group characteristics differ across countries, business groups have two particular traits that distinguish them from other organizational forms - the existence of multiple ties among individual firms and the presence of an administrative center aimed at coordinating group-affiliated firms (Khanna and Rivkin, 2001).

Studies of business groups were fragmented until recently. However, there has been a growing interest among management and organizational scholars in this subject, especially as it pertains to emerging economies (e.g. Chang and Hong, 2002; Guillen, 2000; Keister, 1998; Khanna and Palepu, 2000; Khanna and Rivkin, 2001). In emerging economies, capital, labor and product markets are characterized by high imperfections, and business groups are seen as organizational solutions for resolving the problems that arise from an inadequate institutional environment (Khanna and Palepu, 1997; Kim, Hoskisson, Tihanyi, and Hong, 2004). According to the institutional and transaction cost theories, business groups act as a substitute for missing external institutions, and they create an efficient business environment for affiliated firms. With some exceptions, mostly related to Japanese groups, the empirical evidence supports the view that business groups are efficient mechanisms for resolving market imperfections (e.g. Chang and Choi, 1988; Keister, 1998; Khanna and Palepu, 1999 and 2000; Khanna and Rivkin, 2001). 
Previous studies of groups have analyzed the relationship between business group affiliation and firm performance, usually at a single point in time. The more advanced, crosssectional studies either compare the performance effects of business group affiliation across a number of emerging countries (e.g. Khanna and Rivkin, 2001), or compare the performance effects of business group affiliation in emerging and developed economies (e.g. Chachar and Vissa, 2005). With few exceptions (e.g. Kedia et al., 2006; Khanna and Palepu, 2000), studies have not investigated whether institutional transition could change the positive effect that business group affiliation has on firm performance (Khanna and Yafeh, 2007). This is a relevant question, as institutional transitions, i.e. fundamental and comprehensive institutional changes, modify the rules of the game and affect company behavior and performance (e.g. North, 1990; Peng, 2003).

Therefore, this article investigates the impact of the evolution of the institutional environment on the performance of group-affiliated firms. Following institutional and transaction cost theories, we hypothesize that group-affiliated firms benefit from a superior form of governance in the early phase of institutional transition, but they lose their advantage to unaffiliated firms in the late phase. In line with several recent studies, we also hypothesize that the impact of institutional evolution will vary for different group-affiliated firms. More specifically, we hypothesize that younger firms and service group-affiliated firms are better able to cope with institutional transition than older firms and manufacturing group-affiliated firms.

To test the longitudinal two-phase model of institutional transition (Peng, 2003), we collected data on Indian firms over a 17-year period. The Indian context is particularly appropriate for our purpose for several reasons. First, Indian groups are particularly diffused and it is relatively easy to identify firms belonging to the different groups. Second, India has undergone institutional transition since the early 1990s, which provides for a sufficiently long 
period in which to analyze the hypothesized relationships. Since our panel data combines time-series and cross-sectional data, we use time-series, cross-sectional regression analyses to test our models.

Our findings show that as the institutional environment evolves: (i) the performance benefits of group affiliation slowly erode, i.e. an affiliated firm's superior performance persists in the early phase and levels out in the late phase of institutional transition; (ii) older group-affiliated firms outperform younger group-affiliated firms; and (iii) group-affiliated service firms outperform group affiliated manufacturing firms. Our study has significant theoretical and empirical implications. First, our findings support the institutional and transaction cost theories of business groups, and extend these theories by adding a two-phase longitudinal component. Second, in line with recent research, our findings suggest that the benefits of group membership differ for different member firms.

This article has four sections. In the first section, we introduce the main characteristics of business groups, develop our theoretical hypotheses and discuss institutional evolution in India. In the second, we present the methods as they relate to the sample, data collection, variables and data analysis. The third section summarizes the results of the statistical analyses. Finally, we conclude the article with a discussion of implications and limitations in the fourth section.

\section{THEORETICAL DEVELOPMENT}

\section{Definition and characteristics of business groups}

"Business groups" are the dominant organizational form in emerging economies. A business group is a collection of legally independent firms that are linked together through multiple ties, which can include cross-ownership, strict market exchanges and social relationships (such as those among influential actors, such as owners or managers). Group-affiliated firms 
are coordinated through these ties in order to achieve common goals (Granovetter, 1994; Leff, 1978; Strachan, 1976). This definition captures two particular features of business groups the presence of multiple ties holding group firms together and the existence of coordinated actions enabled by those ties (Khanna and Rivkin, 2001).

These two features differentiate business groups from other organizational forms, such as independent firms or strategic networks (Khanna and Rivkin, 2001; Yiu, Lu, Bruton and Hoskisson, 2007), in several ways. First, group-affiliated firms are bound together by various overlapping ties, such as cross-ownership, interlocking directorates, market transactions, inter-company loans and social relationships (Goto, 1982). The social and organizational relationships among actors (such as shareholders and managers) that tie member firms together do not exist among independent firms. Second, a core entity (e.g. the founding owner, a financial institution, or a state-owned enterprise) inside business groups usually offers administrative control or managerial coordination to affiliated firms (Leff, 1978; Strachan, 1976). For example, in the largest business group in India, the Tata group of companies, Tata Sons is the core entity responsible for the control and coordination of member firms. Strategic networks do not have a core entity coordinating the operations of member firms.

Business groups are far from uniform across countries. The labels used to define business groups differ. For example, Japanese groups are called "keiretsu”, Latin American groups are known as "grupos economicos” and South Korean groups are called “chaebols” (Granovetter, 1994). Furthermore, the characteristics of business groups differ across countries (Khanna and Yafeh, 2007). Business groups vary along many dimensions, such as the types of ties among affiliated firms (i.e. cross-shareholdings, personal relationships, market exchanges), and in terms of the intensity of coordination inside the group. Due to these differences, the definitions and characteristics of business groups are highly contingent on the institutional 
contexts in which they operate. It is therefore somewhat difficult to compare research work on business groups in various settings because the phenomena under investigation may be substantially different (Khanna and Yafeh, 2007; Yiu et al., 2007).

\section{Theoretical framework for investigating business groups in emerging economies}

The most popular theoretical explanations for the widespread diffusion of business groups in emerging economies are the institutional and transaction cost theories, which are complementary. Institutional theory underlines the view that emerging economies are characterized by ineffective institutions and high imperfections in the markets for capital, labor, and products (North, 1990 and 1991). Transaction cost theory suggests that the internalization of transactions inside business groups may resolve problems arising from these market failures (Williamson, 1975, 1985 and 1991).

Institutional theory. Institutional theory emphasizes the influence of socio-cultural norms and values, as well as the effect of law and the judicial system, on organizational structure and behavior (North, 1990). Institutions are the formal (e.g. political rules, economic rules and contracts) and informal (e.g. codes of conduct, norms of behavior and convention) constraints that regulate economic activities and human behavior. Informal constraints are embedded in a culture and play a role when formal constraints fail (North, 1990). Institutions limit the set of choices individuals and organizations have, thereby providing a stable structure for economic exchanges and reducing uncertainty (North, 1990).

Institutions and the effectiveness of enforcement determine the cost of a transaction. Effective institutions increase the benefits derived from cooperative solutions, while ineffective institutions increase the benefits derived from defection (North, 1991). Institutions evolve incrementally, and the story of an economy's performance can be seen as a story of institutional evolution (North, 1991). In sum, according to this theory: (i) the national 
institutional context has a significant impact on rules of competition, firm strategy, and performance, and (ii) a more efficient institutional context favors market exchanges and the growth of the national economy (e.g. North, 1990; Wan and Hoskisson, 2003).

Transaction cost theory. In transaction cost theory, markets and organizations are seen as alternative mechanisms for managing the exchange of goods, services and financial resources (Coase, 1937; Williamson, 1975 and 1985). Markets and hierarchies are polar modes. Markets provide higher incentives, and favor rapid, independent adaptation to external changes. Hierarchies have stronger administrative controls, and they manage adaptation properly if bilateral dependency is present (Williamson, 1991). Managers must adopt transaction costeconomizing strategies - they must choose the organizational form that minimizes the costs implicit in the transaction (Williamson, 1975). When institutions are developed and efficient, the market acts as a superior form of governance. When institutions are underdeveloped and inefficient, a hierarchy produces better results (Williamson, 1985).

In addition to these pure forms, the transaction cost literature acknowledges the existence and growing diffusion of intermediate organizational forms (Williamson, 1991). Intermediate forms include long-term contracts, franchising, joint ventures, and business groups. These governance forms, also denoted as "hybrids", display intermediate characteristics relative to the pure forms. Hybrids are, in fact, characterized by semi-strong incentives and administrative control, and by semi-strong adaptation to the two types of changes (Williamson, 1991). Intermediate forms are particularly diffused when institutions are not developed and efficient, but some control may avoid abuses from the counterpart, and when there is the need for some incentives to foster efficient behavior among the actors involved in the transaction (Williamson, 1991).

\section{Effect of group affiliation in emerging economies prior to major institutional transition}


Emerging economies are traditionally characterized by high imperfections in the markets for capital, final and intermediate products, and managerial and entrepreneurial talent (e.g. Caves, 1989; Khanna, Palepu and Sinha, 2005; Leff, 1976; Peng and Heath, 1996). In this context, transactions may be particularly costly because formal institutions for trade and contract enforcement are weak, and partners involved in a trade are exposed to opportunistic behavior (Khanna and Rivkin, 2001). The presence of information and contracting problems arising from weak market institutions allows the internal market and group structures to create value. In the absence of specialized intermediaries providing trade, enforcement and communication services, there is an opportunity for groups with the appropriate resources and capabilities to fill the "institutional voids” (Khanna and Palepu, 2000).

According to institutional and transaction cost theories, business groups may be seen as an organizational solution for problems arising from market failures and an inadequate institutional environment (e.g. Encaoua and Jacquemin, 1982; Khanna and Palepu, 1997; Kim et al., 2004). Business groups are created in emerging economies to reduce the high transaction costs in markets for capital (Berglof and Perotti, 1994; Caves and Uekusa, 1976; Daems, 1978; Leff, 1978; Strachan, 1976), entrepreneurial skills (Leff, 1978), intermediate products (Goto, 1982; Kester, 1992), labor (Khanna and Palepu, 1997), and political lobbies (Khanna and Rivkin, 2001). Therefore, business groups may be seen as organizational and administrative devices that aim to reduce the high transactions costs arising from market imperfections (Khanna and Palepu, 2000).

In line with the institutional and transaction cost explanation, some scholars argue that members of a business group can create value through the sharing of the group's valuable resources (Khanna and Palepu, 2000). Empirical evidence shows that firms affiliated with business groups freely share intangible resources, such as $\mathrm{R} \& \mathrm{D}$, advertising or reputation (Chang and Hong, 2002). Moreover, business groups may share key personnel and talented 
managers, and provide their employees with extensive managerial and technical training (Chang and Hong, 2000). Business groups may produce better economic performance by mobilizing intangible resources and human resources across firms, especially in the early stage of economic development when market institutions are poorly developed. At that stage, they are in a better strategic position to control they key resources in product and factor markets necessary for the smooth functioning of day-to-day operations. Moreover, groupaffiliated firms have broader, relatively easy access to capital, both internal and foreign, and can access labor and product markets at a lower cost than firms that are not part of a business group (Khanna and Rivkin, 2001).

Group affiliation not only involves benefits but also costs. Khanna and Palepu (2000) mention at least three sources of costs. First, there could be a conflict of interest between the controlling majority shareholders and the minority shareholders, which could result in a misallocation of capital and cross-subsidization of unprofitable ventures by the profitable ones (Zattoni, 1999). Second, there could be inefficient compensation schemes across group firms, as holding companies can move internal resources among group firms either for efficiency or equity reasons. Third, decisions made at the head office may be suboptimal, as it is difficult to acquire expertise in multiple domains at the same time. Chu (2004) suggests that other costs of group affiliation may arise out of the information processing limits of organizations and top management.

Despite the presence of some costs for group affiliation, the general view is that the benefits of group membership outweigh the costs in emerging economies. Empirical evidence supports the hypothesis that firms belonging to a group in an emerging economy show better financial performance than independent firms. Affiliated firms outperform unaffiliated firms in Korea (Chang and Choi, 1988), Chile and India (Khanna and Palepu, 2000). A recent study investigating the in-country performance effects of business groups in 14 emerging 
economies shows that group-affiliated firms outperform unaffiliated firms in the majority of countries (Khanna and Rivkin, 2001). Only in Japan, a developed economy, have members of bank-centered groups been shown to underperform comparable unaffiliated firms for many years (Caves and Uekusa, 1976; Khanna and Yafeh, 2007).

In summary, theory and empirical evidence concur that business groups have beneficial effects in emerging economies. The institutional and transaction cost theories suggest that business groups may improve the profitability of member firms by filling the voids left by the lack of institutions that otherwise ensure the efficient functioning of product, capital, and labor markets (e.g. Khanna and Palepu, 1997; Kim et al., 2004). Empirical evidence provides ample support for the idea that business groups serve as organizational responses to the particular institutional context of emerging economies (e.g. Chang and Choi, 1988; Khanna and Palepu, 2000; Khanna and Rivkin, 2001).

\section{Effect of group affiliation in emerging economies in the early phase of institutional transition}

The institutional environment evolves through marginal adjustments over time (North, 1990: 83). Although institutions evolve throughout relatively long periods of equilibrium, their development is sometimes punctuated by institutional transitions (Peng, 2003). Institutional transitions are "fundamental and comprehensive changes introduced to the formal and informal rules of the game that affect organizations as players” (Peng, 2003: 275). Large-scale institutional transitions imply a deinstitutionalization, i.e. the erosion or the discontinuity of an institutionalized organizational practice (Oliver, 1992). The deinstitutionalization erodes and challenges existing organizational routines and competencies, and may undermine the beneficial effects of business group affiliation. 
Peng (2003) develops a two-phase model of market-oriented institutional transitions. He observes that market-oriented institutional transitions imply a movement from one primary mode of exchange, known as relationship-based contracting, to another mode, known as rulebased contracting, in order to reduce uncertainty. In the first phase, the transition introduces uncertainty, as new institutions emerge to replace old ones (Oliver, 1992). In the short run, the transactions are still dominated by the relationship-based structure, but they gradually move to a rule-based structure in the long run. The long period of incremental evolution may be explained by the lack of credible enforcement of the new rules, and the inertia and resistance emanating from existing organizational routines (North, 1990; Oliver, 1992; Peng, 2003).

The evolution of market institutions leads to an improvement in business competition (Luo and Chung, 2005). Deregulation and privatization remove obstacles to resource mobility and market competition, creating a number of business opportunities. The value of business groups' internal market capabilities declines over time as market institutions develop in the national economic system (Khanna and Palepu, 2000; Peng, 2003). However, in the early phase of transition, the market infrastructures remain relatively underdeveloped. The void in market institutions for labor, capital, and products still creates uncertainty and ambiguity for organizations (Peng, 2003).

There is a time lag between the removal of restrictive policies and the establishment of effective market institutions. The development of market institutions usually takes longer because of the presence of strict interrelationships among them (Aoki and Kim, 1995). In the early phase of institutional transition, competition intensifies and underdeveloped market infrastructures are present (Gemawhat and Khanna, 1998). During this phase, uncertainties in formal institutional constraints often lead managers to rely on informal and interpersonal relationships (Peng and Heath, 1996). As the economy develops and transactions become 
more specialized, informal dealings based on relationships are likely to be the most efficient way of exchange, as formal institutions are still absent (Peng, 2003).

Some empirical studies of emerging economies indicate that group-affiliated firms still outperform unaffiliated firms in the early phase of transition. These studies show that business groups react to the evolution of the institutional environment by increasing their efficiency and improving their performance in the short term (e.g. Kedia et al., 2006; Luo and Chung, 2005). This is possible through strategic actions, such as exiting from some peripheral businesses, making significant investments in new lines of business opened by liberalization, and strengthening internal structures and processes to heighten the group's role as an intermediary (Chang and Hong, 2000; Guillen, 2000; Kedia et al., 2006; Khanna and Palepu, 1999 and 2000; Luo and Chung, 2005).

We hypothesize that:

Hypothesis 1: In the early phase of institutional transition, the performance of groupaffiliated firms is higher than the performance of unaffiliated firms.

\section{Effect of group affiliation in the late phase of institutional transition}

In the early phase of institutional transition, new players - such as entrepreneurial start-ups and foreign entrants - introduce new norms of competition centered on capability development. Until new formal rules are introduced and reinforced, this rule-based structure is not particularly efficient and has little influence on incumbents (Peng, 2003). However, as the transition unfolds, new firms become central players, making market-based competition the new institutionalized way of managing transactions (Leblebici, Salancik, Copay and King, 1991).

Later in the process, institutional transition typically results in increased openness towards cross-border trade and investment, and competitive pressures from foreign multinational 
companies increase (Lee, Peng and Lee, 2008). Capital markets become better regulated, and more open and transparent. At the same time, labor and product markets become more competitive. Finally, the development of market intermediaries in the capital, labor, and product markets favors a rule-based structure and undermines relationship-based dealings (Khanna and Palepu, 1999).

With institutional transition, information progressively flows more freely in the economy, contract enforcement becomes more efficient, and market imperfections and transaction costs are drastically reduced. In these circumstances, the group’s benefits in terms of overcoming imperfections in capital, product, and labor markets decrease substantially (Guillen, 2000; Kim, Hoskisson and Wan, 2004). The evolution of institutional environments inevitably diminishes the value-creating potential of business groups by introducing internal capital, labor, and product markets across the affiliated firms (Khanna and Palepu, 2000). However, despite the pressure exerted by formal market-supporting institutions to change strategy, business groups are slower than unaffiliated firms to move from relationship-based to rulebased competition because they are deeply embedded in the old institutions (Oliver, 1992; Peng, 2003).

This leads to the following hypothesis:

Hypothesis 2: The superior performance of group-affiliated firms relative to unaffiliated firms levels out, over time, in the late phase of institutional transition.

\section{Impact of firm characteristics on the performance effect of group affiliation in emerging} economies

Studies of business groups are traditionally based on the premise that the benefits and costs of group affiliation are equally shared among member firms (e.g. Khanna and Palepu, 2000; Khanna and Rivkin, 2001). These studies measure firm performance, discriminating between 
group-affiliated companies and independent companies, as they focus on the value creation potential of groups relative to independent companies.

In line with some recent studies (e.g. Jameson, Sullivan and Constand, 2000; Kim, Hoskisson, and Wan, 2004), this study goes beyond the implicit assumption of homogeneity of the group effect and explores whether group-affiliated benefits differ for different member firms. In particular, we investigate whether firm age and industry competitiveness have an impact on the group effect, as these variables may play an important role in institutional transitions. Older group-affiliated firms may be more prone to strategic inertia than younger group-affiliated firms, and they may be less flexible in terms of adapting to changing external conditions (Hannan and Freeman, 1984; Newman, 2000; Yiu, Bruton, and Lu, 2005). In India, group-affiliated service firms may be better able to cope with institutional transition than group-affiliated manufacturing firms because the Indian service industry has traditionally been more competitive and efficient than the Indian manufacturing industry (Kapur and Ramamurti, 2001; Porter, 1990).

Firm age and group effect. The "time-period of existence" can affect the firm's distinct bundle of critical resources and organizational skills. Consequently, it may influence the firm's financial performance. In general, the higher the age of the company, the greater the firm's embeddedness and legitimacy in the institutional environment (Yiu, Bruton and Lu, 2005).

The institutional transition implies that this legitimacy is no longer valid, as the institutional context moves from relationship-based to market-based rules of competition (Peng, 2003). The transition requires the development of "strategic flexibility", which helps firms take advantage of new opportunities (Uhlenbruck, Meyer and Hitt, 2003). Firms formed during a certain period are imprinted with the social, cultural, and technical features prevailing in the external environment (Stinchcombe, 1965). Such imprinting may be highly 
resistant to change and is likely to affect firms throughout their life cycle. Old firms are more prone to strategic inertia than young firms, and they are less flexible in terms of adapting to changing external conditions (Hannan and Freeman, 1984).

The extent of a firm's embeddedness in old institutions may be problematic in terms of long-term performance and may even challenge a firm's survival (Newman, 2000). In other words, older firms formed in response to policy distortions would perform worse when such distortions vanish and institutions evolve. We therefore hypothesize that:

Hypothesis 3: Younger group-affiliated firms are better able to cope with institutional transition than older group-affiliated firms.

Industry competitiveness and group effect. The competitiveness of industries and the development of market-based institutions are related (Peng. 2003). In other words, the more competitive an industry, the more advanced the development of market-supporting institutions in that industry. The degree of competitiveness of industries within a nation is far from uniform (Porter, 1990). Some industries may be competitive and integrated in the international arena, while others may be regulated and local (Porter, 1990). In this respect, India shows surprising strength in skill-intensive tradable services, while Indian manufacturing does not demonstrate a similar dynamism (Kapur and Ramamurti, 2001). The development of Indian software and service firms rests on the intensive use of resources (human capital and physical infrastructure) in which the country enjoys an international competitive advantage (Porter, 1990). Rivalry in the Indian software industry has been strong because it has not been subject to industrial licensing from the central government and policies have been supportive of a software industry. In addition, the formation of new 
ventures has been fueled by local and overseas Indians who have started new companies or supplied venture capital (Kapur and Ramamurti, 2001).

In India, knowledge-intensive services such as software, IT, engineering, and healthcare, also dominate international expansion. Some emerging economies are not only beginning to develop a significant share of service exports and FDI, but they are also doing so at far higher growth rates than in manufacturing (Braga, 1996; Svetlicic and Rojec, 2003). These sectors are less prone to severe adaptation or assimilation costs given the standard nature of the offerings. Furthermore, the social and relational capital has been effective in providing knowhow, market access, capital, and overall guidance, even abroad (Kapur and Ramamurti, 2001). In the majority of service sub-sectors, such as information technology, advertising, and engineering services, the comparative capital costs are lower, and operations can be scaled up or replicated at home or in foreign locations fairly easily. In sum, we hypothesize that:

Hypothesis 4: Group-affiliated service firms are better able to cope with institutional transition than group-affiliated manufacturing firms.

\section{METHOD}

\section{Institutional evolution in India}

Discontinuous and fundamental changes are peculiar characteristics of emerging economies. These countries offer a natural, experimental condition in which to explore the impact of the emergence of new formal and informal rules on the strategy and performance of group and independent firms (Peng, 2003; Scott, 1995).

India serves as a classic example of an emerging economy undergoing institutional transition. Liberal trade and FDI policies have been steadily introduced since the early 1990's. Prior to the start of the liberalization process in 1991, India had many market imperfections 
(Douma, George and Kabir, 2006). First, the market for corporate control was almost absent. There were legal restrictions on the acquisition of shares, and the domestic financial institutions were passive. Second, many Indian corporations were managed by family members, which meant that the market for corporate managers was far from effective. Third, the product market was shielded from foreign competition by tariffs and other regulations. In general, the characteristics of the capital, managerial, and product markets were typical of an emerging economy (e.g. Khanna and Palepu, 1999; Kedia et al., 2006).

In India's economic history, the liberalization drive initiated in 1990-1991 can be characterized as a watershed event, which fundamentally changed the competitive landscape for domestic firms. The liberalization was brought about through widespread market reforms, reduction of licenses and regulations, and private participation in state-owned enterprises in a variety of industries. Although the 1990-1991 liberalization served as an exogenous shock in the form of comprehensive institutional reforms (Chittoor, Sarkar, Ray and Aulakh, 2009) with long-term consequences on firm strategy and structure, two aspects of this liberalization drive are relevant to this study. First, the economic reforms undertaken on the governmental level in 1990-91 were not immediately matched by regulatory policy changes on the ground level (Virmani, 2004). The bureaucracy that plagued most government offices in India ensured a lag between the formulation of reforms and policies, and actual institutionalization on the ground level. Such delays in keeping up with policy and regulatory reforms, along with administrative hassles, had a negative impact on investors' enthusiasm during the initial phase of institutional evolution after 1991. Second, the 1990-1991 reforms marked only the beginning of the liberalization drive in the Indian economy. This process has continued and is far from complete, primarily due to the political constraints imposed by coalition governments (Elango and Pattnaik, 2007), a consistent feature of the Indian government over the last two decades. Therefore, we posit that although 1990-1991 brought the biggest 
changes in the institutional evolution of India, the effects could only begin to be observed a few years later, at which point the scope of the liberalization drive gained momentum. We select 1995-1996 as the timeframe for when the latter phase of the institutional evolution commenced. While a detailed review of the institutional reforms and policies is beyond the scope of this article, we would like to highlight several important events that reinforce the choice of 1995-1996 as the dividing line between the two phases of institutional evolution in India.

The Indian capital market was largely underdeveloped, with illiquid equity markets, nationalized banks and a weak monitoring system (Khanna and Palepu, 1997 and 2000), but went through major reforms in 1990-1991. However, incidents of insider trading, stock market scandals and other similar capital frauds were seen following the reforms (Goswami, 2002). In 1992, the Securities and Exchange Board of India (SEBI) was made a statutory body responsible for regulating the capital markets, but SEBI was not empowered to regulate all capital market intermediaries until 1995-1996. The first formal corporate governance committee was only established in 1996. Since then, a number of committees have been formed to provide recommendations on important corporate governance matters, such as board composition and procedures, the constitution of audit committees, and shareholder rights (Rajagopalan and Zhang, 2008). The Ministry of Finance and SEBI cooperated in the introduction of regulations on all aspects of the capital markets, and both drew on global norms and expertise. In August 1994, India accepted IMF Article VIII, whereby the Indian rupee became officially convertible on the current account, allowing foreign institutional investors to more freely take money out of India. This, in turn, increased confidence in the Indian economy. Another notable change was establishment of electronic trading in 1994. All of these changes resulted in a stock market boom in India around the mid-1990's. Firms could access capital through equity markets that were more developed and better regulated than ever 
before. This particularly benefited small, unaffiliated firms that did not otherwise have many options to finance their operations.

The Reserve Bank of India (RBI), India’s central bank, adopted several decontrol measures and regulatory reforms in its efforts to remove policy distortions in the banking sector following the 1991 liberalization. Most of the previous policy framework was dismantled, although there were few immediate changes in terms of government ownership of banks and credit allocation conditions (Virmani, 2004). After 1995-1996, RBI opened up to outside input and consultation from the Finance ministry, local experts and global financial institutions. After this shift, significant private investment, including investment from foreign players, started spread in the banking industry. Bank financing became more readily available, and it came at cheaper rates for domestic firms, which helped those firms that did not operate under the umbrella of larger business groups.

Until the 1991 reforms, the Indian product market was characterized by limited enforcement of liability laws, little dissemination of information and a lack of activist consumers (Khanna and Palepu, 1997 and 2000). This was largely the result of a lack of competition, ensured by strict licensing requirements and high tariffs, which prohibited domestic and foreign private investment. As part of the 1990-1991 reforms, licensing requirements were abolished, except for licenses for firms in defense and industries that could damage the environment. FDI of up to 51\% equity was allowed in select industries (Bhaumik, Gangopadhyay and Krishnan, 2008). This led to a spurt in private participation in a range of industries, which created greater competition. In 1996, the value of equity of private firms finally exceeded that of state-owned enterprises (Majumdar, 2008), which reflected the growing private participation in the Indian economy.

In the 1990's, tax and trade policy reforms were instrumental in boosting consumption and corporate investment, which then led to increased competition in the product market. Taxes 
were reduced across board - the boldest reduction occurred in 1997-98 when the peak personal income tax rate was lowered to $30 \%$ and the corporate tax was lowered to $35 \%$ from the 1980's highs of 56\% and 52\%, respectively (Virmani, 2004). While this created relatively more disposable income for personal consumption, it also enabled firms, particularly smaller ones, to retain larger portions of their profits for investment purposes. On the trade policy front, a major import policy reform in 1995 put 78 consumer goods into the "freely importable” category. In addition, the peak rate for import tariffs was reduced from $85 \%$ in 1993-94 to 50\% in 1995 and to 40\% in 1997-98 (Virmani, 2004). These reforms resulted in a more competitive product market with a significant increase in the dissemination of corporate information.

Prior to the 1990-91 reforms, the Indian labor market was characterized by inflexibility, a scarcity of management talent, few opportunities for training, and the presence of few business schools (Khanna and Palepu, 1997, 2000). Labor market reforms have since been introduced, albeit slowly. The laws governing employment contracts in India are some of the strictest in the world, but they only apply to the organized manufacturing sector, where they restrict labor mobility and force the organized sector to become capital-intensive. Manufacturing plants with more than 100 employees need government permission to lay off even one worker. However, this rule does not apply to establishments in the service sector. In addition, protection for temporary workers, workers on fixed-term contracts and for smaller firms (less than 100 employees) in all sectors is similar to the OECD average (OECD, 2007).

In terms of institutions of higher education, India has made significant progress since 1991. The number of academic institutions for higher learning more than doubled from 6,761 in 1991 to 14,143 in 2003. This resulted in a much larger pool of qualified workers in India. The number of doctoral degrees awarded in science and engineering increased by $81 \%$ from 5,049 in 1996 to 9,131 in 2000 (www.indiastat.com). According to a survey undertaken by The 
Economist, India was ahead of China, the US, the EU and Japan in terms of the total number of university graduates in science and engineering from 2002 to 2004. All of these changes resulted in a much higher employment growth rate in the 2000-2006 time period, reflecting the upward shift of India’s labor market performance (Dougherty, 2008).

Clearly, the liberalization drive led to the globalization of product, labor and capital markets, which in turn affected the way Indian firms governed themselves. Specifically, unaffiliated firms started to change their corporate governance systems to align with global governance standards (Khanna and Palepu, 2004). On the other hand, business groupaffiliated firms continued to depend on their internal product, labor and capital markets and did not feel pressured to comply with the global corporate governance standards. One case representing the former is Infosys and, more generally, the Indian software sector, where many firms started to raise money from the capital markets in India and abroad. In order to do so, they had to be more transparent and follow the same governance mechanisms as publicly listed firms in the west.

\section{Sample and variables}

The data used in this study covers 547 Indian firms over a 17 year period (1990 to 2006). The list of firms was derived from the 2006 edition of the annual database, Prowess, which is compiled by the Center for Monitoring the Indian Economy (CMIE) ${ }^{1}$. The database covers the majority of public Indian firms and is compiled by CMIE using audited annual reports that are provided by the firms. The Prowess database provides information on the identity of the owner(s), through which one can identify whether a firm is business group- affiliated, foreignowned or privately held. In addition, the database also provides a range of financial information on the firms. 
Following along the lines of previous studies (e.g. Khanna and Palepu, 2000), this study focuses on a consistent sample of firms for which there was 17 years of complete data and for which group affiliation was stable over time. Robustness checks were undertaken with broader samples. This sample allowed us to compare the same firms over time (i.e. the firm variation is constant), and it was not affected by entries and exits, which made it possible to distinguish the effects of institutional changes on firm behavior and performance.

After cleaning the data and accounting for missing information, the final sample had 9,299 useable observations (547 firms, 17 years), which makes it a large, unique sample. A total of 403 firms were affiliated with business groups, while 144 were privately held, unaffiliated firms.

\section{Measures and analysis}

Dependent variable. The dependent variable, Financial Performance, is measured as the return (profit after tax) on sales, which is otherwise known as ROS. ROS is a commonly used financial performance measure for Indian firms. Robustness tests were conducted on other performance measures, such as return on assets and return on equity, and the results were similar. However, the data for ROS was more complete.

Independent variables. Affiliation to a business group is a dummy variable indicating whether the focal firm belongs to a business group (see Fisman and Khanna, 2004). Business groups are particularly diffused in India (Douma, George and Kabir, 2006). Groups are usually controlled by a family that sets the strategic direction and manages financial transfers among firms. Given the availability of information pertaining to group affiliation, it is relatively easy to identify firms belonging to the same group. Furthermore, firms are usually a member of only one group and they tend to maintain their affiliation. In addition to the main effect of belonging to a business group, we also used an "interaction effect" of "business 
group * time” by multiplying the business group variable by the number of years in our window. The purpose of this variable is to detect changes in the effect of belonging to a business group over time.

Time is a variable measuring the number of years since 1990, which is the year our window starts and when the first reforms were conducted in India. The window covers 17 years (1990-2006), so the time variable take a value of 1 for the year 1990, 2 for the year 1991, and so on (maximum value is 17 for 2006). This variable measures the amount of time, in years, since the reform process started in India. The interaction effect between time and other variables is added in order to detect whether the effect of these variables changes over time as the reform process begins and becomes more widespread.

Age is a variable that measures the age of the firm since inception (number of years). In addition, we have created an interaction effect "age * time" by multiplying the two variables.

Service industry is a dummy variable that specifies whether the firm belongs to a service industry (value of 1 ) or to a manufacturing industry (value of 0 ). The service industries include civil engineering, computer software, construction, trading, health, media and broadcasting, hotel, business consulting, and business process outsourcing (BPO). We did not include financial service firms of any type. In our sample, 77 firms belong to the service industry, while 470 firms focus on manufacturing. In order to test hypothesis 4 , we created the interaction effect "service * time” by multiplying the two variables.

Control variables. We controlled for firm size and industry, as these factors may have an impact on firm performance (Gedajlovic and Shapiro, 1998). Firm size is measured as the logarithm of total assets in Indian rupees. In addition, all firms are categorized into 28 industries. In all models, 27 industry dummies are included to control for differences on the industry level, such as levels of regulation and entry barriers. 
We included two other variables to capture the firm's centrality within individual business groups and the group's diversity. The first measures the firm's share of group assets, i.e. the firm's assets as a share of the total group assets (Claessens, Djankov, Fan and Lang, 2002). It is included as a dummy with a value of 1 if the firm's assets are more than or equal to $25 \%$ of total group assets and a value of 0 if the firm's assets are less than $25 \%$ of total group assets. This variable points to those firms that might be insignificant for the group and therefore may not receive the same benefits as other firms in the group. The second variable measures the diversity of the group based on the number of industries in which the group is present (e.g. Khanna and Palepu, 2000). If the group is present in more than one of the 28 industries, it is categorized as diversified with a value of 1 . Otherwise, the value is 0 . This variable is designed to capture the group's diversity in case firms in more diversified groups benefit more than those in non-diversified groups.

Data analysis. We applied the SAS Procedure TSCSREG (Time-Series, Cross-Section Regression) with a variance component model that uses the Fuller-Battese method in the estimation (SAS, 1999). In this model, the performance of the model parameters depends on the statistical characteristics of the error components in the model. The model has random firm and time effects. The random firm effects (which can be thought of as random intercepts) correct for correlations between observations for a given firm (over the observed 17 years), while the random time effects correct for correlations between observations at the same point in time. The random effects reflect the influence of unobserved variables typical of the individual firms (such as changes in strategy, like mergers or sell-offs) and points in time (such as the market's yearly fluctuations).

Hypotheses 1 and 2 on the performance effects of business group membership given institutional changes are tested on a sample that includes all firms. Hypotheses 3 and 4 are 
tested on a sample that only includes those firms belonging to a business group, as these hypotheses focus on variation among business group-affiliated firms.

\section{RESULTS}

The panel estimation results for the models with random time and firm effects are shown in Table 1. The table includes four models. A Hausman test was conducted for all four models in order to determine whether adding the fixed effects improves the models. The Hausman test was insignificant for all four models. This supports the chosen model, which includes random firm and time effects, as the alternate model with fixed effects (which take up more degrees of freedom) does not perform better than the current model.

Having established validity for our model, we turn to the results of the estimation given in Table 1. In the two first columns, the estimation is conducted over the entire 17 years, while the estimations in the third and fourth column are for 1990-1995 and 1996-2006, respectively. 1990-1995 reflects the early phase of institutional transition in India, while 1996-2006 mirrors the late phase of institutional transition.

Hypothesis 1, on the performance effect of business group membership in the early phase of institutional transition, is most directly tested in the third column, where the business group variable is shown to be significant (coefficient: 0.13, $\mathrm{t}=2.15, \mathrm{p}<0.05$ ) and positive, as expected. In the three other models (in Table 1), the business group dummy is insignificant. In particular, the insignificant parameter for business group in the fourth column (coefficient: $0.20, \mathrm{t}=-0.99, \mathrm{p}>0.10$ ) on the late phase of institutional transition provides evidence for hypothesis 2 - the positive performance effect of belonging to a business group levels out as the institutional transition progresses. The highly significant and negative interaction effect in column 2 (coefficient: $-0.04, \mathrm{t}=-3.46, \mathrm{p}<0.01$ ) tells the same story - in the context of Indian 
firms, the advantage of being a member of a business group diminishes from 1990-2006 as the institutional transition unfolds.

\section{(Insert here Table 1)}

Table 2 only includes estimates for firms belonging to a business group, which allows for a test of hypotheses 3 and 4 . Both hypotheses are tested simultaneously in the model presented in Table 2, which includes the main effects of age and service industry as well as their interaction effects with time. The main effect of age is insignificant (coefficient: $0.01, t=0.27$, $\mathrm{p}>0.10$ ), while the interaction effect (age * time) is positive and significant (coefficient: 0.01, $\mathrm{t}=2.12, \mathrm{p}<0.05)$. This indicates that older firms belonging to a business group are better able to cope with the new institutional environment in a transition, which is contrary to hypothesis 3. For group-affiliated service firms, the main effect, and the interaction between service firm and time are highly significant and positive [coefficients: $0.91(t=3.23)$ and 0.06 ( $\mathrm{t}=3.15$ ), respectively, and both $\mathrm{p}<0.01]$. This signifies that business group-affiliated firms in services perform better than those in manufacturing. Furthermore, the gap between these firms increased as the institutional transition in India unfolded, as suggested in hypothesis 4.

In four of the five models, the control variable "logarithm of total assets" is significant (at $\mathrm{p}<0.01$ ), which implies that size is important. Size consistently has a positive effect on the level of performance. The parameters of the 27 industry dummies are not presented in the tables. Generally, the industry dummies are insignificant, with 3-5 significant industry dummies in each model. This indicates that industry differences are not a major issue in this data. However, the control variables referring to the group level, i.e. "share of group" and “diversity of group”, are not significant in any of the five models, which indicates that these variables have no impact on the performance of Indian firms. 
(Insert here Table 2)

\section{DISCUSSION}

Our findings contribute to the understanding of the link between firm performance and institutional evolution. They show that: (i) business group-affiliated firms outperform unaffiliated firms in the early phase of transition, while they lose their advantage in the late phase of transition; (ii) the benefits of group membership differ for different member firms; and (iii) a time-series, cross-sectional approach may improve the reliability of findings on the effects of group membership during institutional transition.

Group-affiliated firms' performance during institutional evolution. Theoretical contributions and empirical evidence suggest that group-affiliated firms may show superior performance in emerging economies (e.g. Chang and Choi, 1988; Keister, 1998; Khanna and Palepu, 1999 and 2000; Khanna and Rivkin, 2001). The rationale is that labor and product markets are characterized by larger imperfections in emerging economies, and that the internalization of market transactions may lead to superior performance in these situations (Peng, Lee and Wang, 2005).

Some recent research highlights the possibility that the group effect may decrease over time as markets become more efficient (Chang and Hong, 2002; Khanna and Palepu, 2000). Our study supports this view and extends it by adding a two-phase longitudinal framework (Peng, 2003). Our results show that in early periods of institutional transition, which are characterized by market imperfections and weak institutions, group-affiliated firms perform better than unaffiliated firms. In subsequent periods characterized by greater market efficiency and stronger institutions, group-affiliated firms lose their superior performance. Therefore, our findings support and extend the institutional and transaction cost theories of 
business groups through the analysis of the group effect during the early and the late phases of institutional transition.

The reasoning behind the two-phase model of institutional transition is related to environmental and group features. First, there is usually a time lag between the removal of restrictive policies and the establishment of effective institutions (North, 1990; Peng, 2003). Moreover, the development of market intermediaries in the labor, capital and product markets takes time. However, when this development is complete, rule-based interactions are favored and relationship-based dealings are undermined (Aoki and Kim, 1995; Khanna and Palepu, 1999). Second, some empirical studies show that business groups react to the institutional transition by taking strategic actions aimed at improving internal efficiency (e.g. Chang and Hong, 2000; Kedia et al., 2006; Khanna and Palepu, 1999 and 2000; Luo and Chung, 2005). These strategies are effective in the short term, but they cannot avoid the leveling-out of group-affiliated firms’ performance as the institutional transition unfolds (e.g. Guillen, 2000; Khanna and Palepu, 2000; Kim et al., 2004; Peng, 2003). Our findings support this two-phase model of institutional transition, and encourage governance scholars to investigate the actual mechanisms of how changes in the market and institutional environment affect firm performance (e.g. Kedia et al., 2006).

Heterogeneity of group membership benefits for different member firms. Traditional literature on business groups rests upon the premise that the benefits and costs of group affiliation are shared equally by member firms (Khanna and Rivkin, 2001). Prior research failed to address whether heterogeneity among member firms could influence the appropriation of the benefits arising from group affiliation (Kim et al., 2004). The conceptualization and empirical analysis of this interesting question are still relatively underdeveloped. 
However, some recent research indicates that the benefits of membership may vary for different firms (Kim et al., 2004; Jameson, Sullivan and Constand, 2000). In particular, these findings indicate that some members enjoy more benefits than others depending on their power-dependence position in the group (Kim et al., 2004; Jameson et al., 2000). Our findings also suggest that the benefits of membership vary for different member firms. In fact, our results indicate that the influence of the institutional transition on the performance of groupaffiliated firms differs based on the age of the firms and the sector in which they are involved (manufacturing versus services). In particular, older firms and service firms are better able to cope with institutional transition than younger firms or manufacturing firms belonging to business groups.

The superior performance of group-affiliated service firms during the institutional transition is in line with our expectations, while the superior performance of older firms is not. Some factors may help explain the unexpected relationship between age and firm performance. First, old firms are more experienced, command greater reliability and legitimacy, receive the benefits of learning, and are associated with first-mover advantages (Douma, George and Kabir, 2006). On the other hand, young affiliated firms do not have stable relationships and may have fewer resources (Baum, Calabrese and Silverman, 2000). Second, old firms may have higher centrality inside the group and stricter relationships with other firms in the group. They may benefit from the strategy of the group to react to new environmental conditions, which intensifies existing relationships, and they may be able to exploit available group capabilities and resources (Khanna and Palepu, 1999). At the same time, young firms may not have a central position in the group or established relationships with other group firms. This may negatively affect their performance in a period of institutional change or group difficulties. As centrality in the group is not significant, our study indicates that some group market and organizational mechanisms may provide more 
benefits to older companies than younger ones as institutionalization takes place. These mechanisms may be represented by social and organizational relationships (e.g. market transactions, financial loans, social and family ties) that modify - for some unexplored reasons - the effect of institutional transition on member companies. Our findings support the idea that the benefits of group membership differ among firms, and we encourage governance scholars to further explore the impact of group membership on different types of member firms (Kim et al., 2004; Jameson et al., 2000).

Longitudinal versus cross-sectional studies. Previous work has been criticized because it adopted a static approach and was based on cross-sectional data (Newman, 2000). The more advanced cross-sectional studies compare the performance effects of business group affiliation in a number of emerging economies to explore whether these effects are stable across countries (e.g. Khanna and Rivkin, 2001). Alternatively, cross-sectional studies contrast the performance effects of business group affiliation in emerging and developed economies to measure the different effects of group affiliation in the two environments (e.g. Chachar and Vissa, 2005). Due to their cross-sectional approach, previous studies failed to provide temporal benchmarks for organizational transformations (Newman, 2000).

The market and the institutional environment in emerging economies evolve over time through marginal adjustments and major institutional transitions (e.g. Peng, 2003). Although marginal adjustments may not radically change the informal and formal rules of the game, the institutional transitions erode existing firms’ routines and competencies (Oliver, 1992; Peng, 2003) and may undermine the beneficial effects of group affiliation. However, only a few studies (e.g. Kedia et al., 2006; Khanna and Palepu, 2000) have investigated the persistence of the positive effect of business group affiliation on firm performance over a longitudinal time period (Khanna and Yafeh, 2007). 
Our study goes beyond the main criticism of cross-sectional studies, i.e. that they are heavily influenced by the sample period (Peng et al., 2005), to analyze the business group effect over a long period of institutional transition. We have chosen a long sample period with a constant cohort of firms, which allows us to track the dynamics between institution and market forces on the one hand, and group-affiliated and unaffiliated firms' performance on the other. Our findings contribute to the understanding of the group effect during the early and late phases of institutional transition in India, and we encourage governance scholars to investigate the group effect over long periods in other emerging economies (Newman, 2000; Peng, 2003).

Managerial implications. This paper has also implications for practitioners. First, managers of business groups should follow the evolution of the institutional environment carefully and adapt group characteristics accordingly. As the institutional context evolves, the benefits of being affiliated with the group may diminish, and new strategies should be developed. Firms failing to adapt to new institutions may find that their fit with old institutions is unable to support future performance, and that it may even threaten the firm's survival (Wright, Filatotchev, Hoskisson, and Peng, 2005). Second, policy makers should focus on the short-term consequences of policies aimed at developing market efficiency. Policy makers reshape the business and institutional environments of emerging economies through waves of deregulation. In some countries, they have advocated the shrinking of business groups to foster efficiency and the welfare of the national economy (Khanna and Rivkin, 2001). Our results suggest that although these policies have the desired strong, longterm effects on the transparency and efficiency of the market, they may undermine the efficiency of large national groups and, given the importance of these groups to the national economy, of the entire economic system. For this reason, policy makers should evaluate costs 
and benefits in the short and long terms, and carefully manage the transition of national companies and groups from old to new institutional contexts.

Limitations and future research. We acknowledge that this study has some limitations. First, group definition varies substantially across countries, and it is problematic to develop a study covering several countries (Khanna, 2000). For this reason, we investigated business groups in a single country, i.e. India. India represents an ideal research setting for this study, as the economy is dominated by large business groups and group membership is clearly defined (Khanna and Palepu, 2000). India is the second-largest emerging economy in the world and its growth rate is second only to China (Kedia et al., 2006). Moreover, in the 1990's, the Indian government started a process of transitioning to a more liberalized, competitive economy. However, our choice may have biased our results because some nationspecific conditions may have influenced the analysis. Future studies may extend our study to cover other countries.

Second, our research does not develop a deep, first-hand understanding of how the market and institutional environment affects the performance of affiliated and unaffiliated firms during the two-phase institutional transition. The actual mechanisms behind how the changes in the market and institutional environment affect group performance remains largely unexplored, as in most previous studies (e.g. Khanna and Palepu, 2000; Khanna and Rivkin, 2001). Future studies could investigate the direct impact of institutional transitions on group strategy and performance (Kedia et al., 2006; Khanna and Yafeh, 2007).

Third, following previous studies on business groups in emerging economies (e.g. Chang and Choi, 1988; Chang and Hong, 2000; Khanna and Palepu, 1999; Khanna and Palepu, 2000; Yiu, Bruton and Lu, 2005), we measured group and firm performance using accounting data, i.e. return on sales. The use of accounting measures rather than market-based measures is based on data constraints. It is, in fact, difficult to find complete, market-based measures of 
firm performance in emerging economies. This is especially true if the study covers a large sample over a long time period (Khanna and Palepu, 1999; Khanna and Rivkin, 2001). Future studies may fill this gap by taking advantage of the availability of longer, more complete series of market and accounting-based performance data.

\section{CONCLUSION}

Our research investigates the link between firm performance and the evolution of the institutional environment in emerging economies. Our findings support institutional and transaction cost theories, as they show that: (i) when labor, capital, and products markets are characterized by large imperfections and weak supporting institutions - as they are prior to institutional transition and in the early-phase of institutional transition - business groups outperform independent companies; (ii) when markets become more efficient and institutions grow stronger - as they do in the late phase of institutional transition - group-affiliated firms fail to show continued superior performance; (iii) heterogeneity among member firms (e.g. old versus young firms, manufacturing versus service firms) may influence the appropriation of the benefits arising from group affiliation.

These findings expand the traditional understanding of the relationship between firm performance and the institutional context in emerging economies, and provide further support for the idea that the relative performance of group-affiliated firms is contingent upon the characteristics of the institutional context (i.e. market imperfections and strength of supporting institutions) and their particular features (i.e. group versus independent firms and other specific features of firms). 


\section{Notes}

1. Other international business and strategy scholars have used this database to study Indian firms (e.g. Bertrand, Mehta and Mullainathan, 2002; Chacar and Vissa, 2005; Elango and Pattanaik 2007; Fisman and Khanna, 2004) and provided a positive rating of the overall quality and accuracy of this source. 


\section{REFERENCES}

Aoki, M. and Kim, H. (eds.) (1995) Corporate Governance in Transitional Economies: Insider Control and the Role of Banks. Washington: Economic Development Institute of World Bank.

Baum, J.A.C., Calabrese, T. and Silverman, B.S. (2000) Don’t Go it Alone: Alliance Networks and Startup Performance in Canadian Biotechnology, Strategic Management Journal, 21(3), 267-294.

Berglöf, E. and Perotti, E. (1994) The Governance Structure of the Japanese Financial Keiretsu, Journal of Financial Economics, 36 (2), 259-284.

Bertrand, M., Mehta, P. and Mullainathan, S. (2002) Ferreting Out Tunneling: An Application To Indian Business Groups, The Quarterly Journal of Economics, 117(1), 121-148.

Bhaumik, S.K., Gangopadhyay, S. and Krishnan, S. (2008) Policy, Economic Federalism and Product Market Entry: The Indian Experience, The European Journal of Development Research, 20 (1), 1-30.

Braga, C.A.P. (1996) The Impact of the Internationalization of Services on Developing Countries, Finance \& Development, 33 (1), 34-37.

Caves, R. and Uekusa, M. (1976) Industrial Organization in Japan. Washington: The Brookings Institution.

Caves, R.E. (1989) International differences in industrial organization. In Schmalensee, R. and Willig, R.D. (eds) Handbook of Industrial Organization II, Amsterdam: Elsevier.

Chacar, A. and Vissa, B. (2005) Are Emerging Economies less Efficient? Performance Persistence and the Impact of Business Group Affiliation, Strategic Management Journal, 26 (10), 933-946. 
Chang, S.J. and Choi, U. (1988) Strategy, Structure and Performance of Korean Business Groups: A Transactions Cost Approach, Journal of Industrial Economics, 37(2), 141-158.

Chang, S.J. and Hong, J. (2000) Economic Performance of Group Affiliated Companies in Korea: Intragroup-resource Sharing and Internal Business Transactions, Academy of Management Journal, 43 (3), 429-448.

Chang, S.J. and Hong, J. (2002) How Much does the Business Group Matter in Korea? Strategic Management Journal, 23 (3), 265-274.

Chittor, R., Sarkar, M.B., Ray, S. and Aulakh, P.S. (2009) Third-World Copycats to Emerging Multinationals: Institutional Changes and Organizational Transformation in the Indian Pharmaceutical Industry, Organization Science, 20(1), 187-205.

Chu, W (2004) Are Group-Affiliated Firms Really More Profitable than Nonaffiliated? Small Business Economics, 22 (5), 391-405.

Claessens, S., Djankov, S., Fan, J.P.H. and Lang, L.H.P. (2002) Disentangling the Incentive and Entrenchment Effects of Large Shareholdings, Journal of Finance, 57 (6), 2741-2771. Coase, R.H. (1937) The Nature of the Firm, Economica, 4, 386-405.

Daems, H. (1978) The Holding Company and Corporate Control. Boston: M. Nijhoff, Social Sciences Division.

Dougherty, S.M. (2008) "Labor regulation and employment dynamics at the state level in India“, Economics Department Working Paper \#64, OECD.

Douma, S., George, R. and Kabir, R. (2006) Foreign and Domestic Ownership, Business Groups, and Firm Performance: Evidence from a Large Emerging Market, Strategic Management Journal, 27 (7), 637-657.

Elango B. and Pattnaik, C. (2007) Building Capabilities for International Operations through Networks: A Study of Indian Firms, Journal of International Business Studies, 38 (4), 541-555. 
Encaoua, D. and Jacquemin, A. (1982) Organizational Efficiency and Monopoly Power, European Economic Review, 19: 25-51.

Fisman, R. and Khanna, T. (2004) Facilitating Development: The Role of Business Groups, World Development, 32 (4), 609-628.

Gedajlovic, E.R. and Shapiro, D.M. 1998. Management and ownership effects: evidence from five countries, Strategic Management Journal, 19: 533-553.

Ghemawat, P. and Khanna, T. (1998) The Nature of Diversified Business Groups: A Research Design and Two Cases Studies, Journal of Industrial Economics, 46 (1), 35-61.

Goswami, O. (2002) Corporate Governance in India. Taking Action Against Corruption in Asia and the Pacific, Asia Development Bank, 85-106.

Goto, A. (1982) Business Groups in a Market Economy, European Economic Review, 19 (1), 53-70.

Granovetter, M. (1994) Business groups. In Smelser, J.N. and Swedberg, R. (eds.) The Handbook of Economic Sociology. Princeton: Princeton University Press.

Guillen, M.F. (2000) Business Groups in Emerging Economies: A Resource-based View, Academy of Management Journal, 43 (3), 362-380.

Hannan, M. and Freeman, J. (1984) Structural Inertia and Organizational Change, American Sociological Review, 49, 149-164.

Jameson, M., Sullivan, M.J. and Constand, R.L. (2000) Ownership Structure and Performance of Japanese Firms: Horizontal Keiretsu, Vertical Keiretsu, and Independents, Review of Pacific Basin Financial Markets \& Policies, 3 (4), 535-556.

Kapur, D. and Ramamurti, R. (2001) India's Emerging Competitive Advantage in Service, Academy of Management Executive, 15 (2), 20-32.

Kedia, B.L., Mukherjee, D. and Lahiri, S. (2006) Indian Business Groups: Evolution and Transformation, Asia Pacific Journal of Management, 23 (4), 559-577. 
Keister, L.A. (1998) Engineering Growth: Business Group Structure and Firm Performance in China's Transition Economy, American Journal of Sociology, 104 (2), 404-440.

Kester, C. (1992) Industrial Groups as Systems of Contractual Governance, Oxford Review of Economic Policy, 8 (3), 24-44.

Khanna, T. (2000) Business Groups and Social Welfare in Emerging Markets: Existing Evidence and Unanswered Questions, European Economic Review, 44, 748-761.

Khanna, T. and Palepu, K. (1997) Why Focused Strategies May be Wrong for Emerging Markets, Harvard Business Review, 75, 41-51.

Khanna, T. and Palepu, K. (1999) Policy Shocks, Market Intermediaries, and Corporate Strategy: The Evolution of Business Groups in Chile and India, Journal of Economics \& Management Strategy, 8 (2), 271-310.

Khanna, T. and Palepu, K. (2000) The Future of Business Groups in Emerging Markets: Long-run Evidence from Chile, Academy of Management Journal, 43 (3), 268-285.

Khanna, T. and Palepu, K. (2004) Globalization and Convergence in Corporate Governance: Evidence from Infosys and the Indian Software Industry, Journal of International Business Studies, 35, 484-507.

Khanna, T. and Rivkin, J.W. (2001) Estimating the Performance Effects of Business Groups in Emerging Markets, Strategic Management Journal, 22 (1), 45-74.

Khanna, T. and Yafeh, Y. (2007) Business Groups in Emerging Markets: Paragons or Parasites? Journal of Economic Literature, 45 (2), 331-372.

Khanna, T., Palepu, K.G. and Sinha, J. (2005) Strategies that fit Emerging Markets, Harvard Business Review, June, 63-76.

Kim, H., Hoskisson, R.E. and Wan, W.P (2004) Power Dependence, Diversification Strategy, and Performance in Keiretsu Member Firms, Strategic Management Journal, 25 (7), 613-636. 
Kim, H., Hoskisson, R.E., Tihanyi, L. and Hong, J. (2004) The Evolution and Restructuring of Diversified Business Groups in Emerging Markets: The Lessons from Chaebols in Korea, Asia Pacific Journal of Management, 21(1/2), 25-48.

Leblebici, H., Salancik, G., Copay, A. and King, T. (1991) Institutional Change and the Transformation of Interorganizational Fields: An Organizational History of the US Radio Broadcasting Industry, Administrative Science Quarterly, 36 (3), 333-363.

Lee, K., Peng, M.W. and Lee, K. (2008) From Diversification Premium to Diversification Discount during Institutional Transitions, Journal of World Business, 43 (1), 47-65.

Leff, N.H. (1976) Capital Markets in the Less Developed Countries: the Group Principle. In McKinnon, R. (ed.) Money and Finance in Economic Growth and Development. New York: Marcel Dekker.

Leff, N.H. (1978) Industrial Organization and Entrepreneurship in the Developing Countries: The Economic Groups, Economic Development and Cultural Change, 26(4), 661-676.

Luo, X. and Chung, C. (2005) Keeping It All in the Family: The Role of Particularistic Relationships in Business Group Performance during Institutional Transition, Administrative Science Quarterly, 50 (3), 404-439.

Majumdar, S.K. (2009) Crowding Out! The Role of State Companies and the Dynamics of Industrial Competitiveness in India, Industrial and Corporate Change, 18(1), 165-207.

Newman, K.L. (2000) Organizational Transformation during Institutional Upheaval, Academy of Management Review, 25 (3), 602-619.

North, D.C. (1990) Institutions, Institutional Change and Economic Performance. Oxford: Oxford University Press.

North, D.C. (1991) Institutions, Journal of Economic Perspectives, 5 (1), 97-112.

Oliver, C. (1992) The Antecedents of Deinstitutionalization, Organization Studies, 13: 563588. 
Peng, M.W. (2003) Institutional Transitions and Strategic Choices, Academy of Management Review, 28(2): 275-286.

Peng, M.W. and Heath, P.S. (1996) The Growth of the Firm in Planned Economies in Transition Institutions, Organizations, and Strategic Choice, Academy of Management Review, 21 (2), 492-528.

Peng, M.W., Lee, S. and Wang, D.Y.L. (2005) What Determines the Scope of the Firm over Time? A Focus on Institutional Relatedness, Academy of Management Review, 30 (3), 622-633.

Porter, M. (1990) The Competitive Advantage of Nations. New York: Macmillan.

Rajagopalan, N. and Zhang, Y. (2008) Corporate Governance Reforms in China and India: Challenges and Opportunities, Business Horizons, 51, 55-64.

SAS (1999) SAS/STAT User’s Guide, Version 8. Cary, NC: SAS Institute.

Scott, W.R. (1995) Institutions and Organizations. Thousand Oaks: Sage.

Sharma, A.N. (2006) Flexibility, employment and labor market reforms in India, Economic and Political Weekly, May 27.

Singh, A. (2007) Policy environment and regulatory reforms for private and foreign investment in developing countries: A case of the Indian power sector, Asia Development Bank Discussion Paper \#64.

Stinchcombe, A.L. (1965) Social Structure and Organizations. In March, J.G. (ed.), Handbook of Organizations. Chicago: Rand McNally \& Company, 142-193.

Strachan, H. (1976) Family and other Business Groups in Economic Development. New York: Praeger Publishers.

Svetlicic, M. and Rojec, M. (eds) (2003) Facilitating Transition by Internationalisation: Outward Direct Investment from Central European Economies in Transition. Aldershot: Ashgate. 
Uhlenbruck, K., Meyer, K.E. and Hitt, M.A. (2003) Organizational Transformation in Transition Economies: Resource-based and Organizational Learning Perspectives, Journal of Management Studies, 40 (2), 257-282.

Virmani, A. (2004) “Economic reforms: Policy and institutions - Some lessons from Indian reforms“, Working paper 121, Indian Council for Research on International Economic Relations.

Wan, W.P. and Hoskisson, R.E. (2003) Home Country Environments, Corporate Diversification Strategies, and Firm Performance, Academy of Management Journal, 46 (1), 27-45.

Williamson, O.E. (1975) Markets and Hierarchies: Analysis and Antitrust Implications. New York: The Free Press.

Williamson, O.E. (1985) The Economic Institutions of Capitalism: Firms, Markets, Relational Contracting. New York: The Free Press.

Williamson, O.E. (1991) Comparative Economic Organization: The Analysis of Discrete Structural Alternatives, Administrative Science Quarterly, 36, 269-296.

Wright, M., Filatotchev, I., Hoskisson, R.E. and Peng, M.W. (2005) Strategy Research in Emerging Economies: Challenging the Conventional Wisdom, Journal of Management Studies, 42(1), 1-33.

Yiu, D., Bruton, G.D. and Lu, Y. (2005) Understanding Business Group Performance in an Emerging Economy: Acquiring Resources and Capabilities in Order to Prosper, Journal of Management Studies, 42 (1), 183-206.

Yiu, D.W., Lu, Y., Bruton, G.D. and Hoskisson, R.E. (2007) Business Groups: An Integrated Model to Focus Future Research, Journal of Management Studies, 44 (8), 1551-1579.

Zattoni, A. (1999) The Structure of Corporate Groups: The Italian Case, Corporate Governance - An International Review, 7 (1): 38-48. 
Table 1: Panel Estimation with random effects, all firms (547 firms)

\begin{tabular}{|c|c|c|c|c|c|c|c|c|}
\hline \multirow[t]{3}{*}{ Variable } & \multicolumn{4}{|c|}{ Return on sales (ROS) } & \multicolumn{4}{|c|}{ Return on sales (ROS) } \\
\hline & \multicolumn{4}{|c|}{ All 17 years } & \multicolumn{2}{|c|}{ Year 1990-1995 } & \multicolumn{2}{|c|}{ Year 1996-2006 } \\
\hline & Coefficient & Std Error & Coefficient & Std Error & Coefficient & Std Error & Coefficient & Std Error \\
\hline Constant & $-0.86 *$ & 0.28 & $-0.87 \dagger$ & 0.27 & 0.03 & 0.13 & $-0.76 \dagger$ & 0.41 \\
\hline Business Group & -0.10 & 0.13 & 0.11 & 0.15 & $0.13^{*}$ & 0.06 & -0.20 & 0.19 \\
\hline Business Group*time & & & $-0.04 * *$ & 0.01 & & & & \\
\hline Logarithm of total assets & $0.22^{* * *}$ & 0.03 & $0.23^{* * *}$ & 0.03 & -0.01 & 0.01 & $0.32^{* * *}$ & 0.05 \\
\hline Age & $0.01^{*}$ & 0.00 & $0.01 \dagger$ & 0.00 & 0.01 & 0.01 & $0.01^{*}$ & 0.00 \\
\hline Service & $0.32 \dagger$ & 0.20 & $0.31 \dagger$ & 0.20 & -0.08 & 0.09 & $0.53 \dagger$ & 0.30 \\
\hline Share of group & -0.13 & 0.14 & 0.13 & 0.14 & 0.01 & 0.07 & -0.20 & 0.22 \\
\hline Diversity of group & 0.12 & 0.13 & 0.12 & 0.13 & 0.01 & 0.06 & 0.08 & 0.20 \\
\hline Industry dummies & $(27$ & & & & $(27$ & & & \\
\hline $\begin{array}{c}N \text { (firm-years) } \\
R \text {-square } \\
\text { Hausman test for random effects }\end{array}$ & & * (2 df) & & (2 df.) & & & & (2 df.) \\
\hline $\begin{array}{c}\text { Variance components } \\
\text { Firm } \\
\text { Time series } \\
\text { Error } \\
\end{array}$ & & & & & & & & \\
\hline
\end{tabular}

$\dagger, *, * *$ and $* * *$ are $10 \%, 5 \%, 1 \%$ and $0.1 \%$ levels of significance, respectively 
Table 2: Panel Estimation with random effects, firms belonging to a business group (403 firms)

\begin{tabular}{|c|c|c|}
\hline \multirow[t]{2}{*}{ Variable } & \multicolumn{2}{|c|}{$\begin{array}{c}\text { Return on sales (ROS) } \\
\text { All } 17 \text { years }\end{array}$} \\
\hline & Coefficient & Standard error \\
\hline Constant & $-0.74 * *$ & 0.28 \\
\hline Age & 0.01 & 0.01 \\
\hline Age*time & $0.01^{*}$ & 0.01 \\
\hline Service & $0.91 * *$ & 0.28 \\
\hline Service * time & $0.06^{* *}$ & 0.02 \\
\hline Logarithm of total assets & $0.27^{* * *}$ & 0.04 \\
\hline Share of group & -0.13 & 0.16 \\
\hline Diversity of group & 0.06 & 0.14 \\
\hline Industry dummies & & \\
\hline $\begin{array}{c}N \text { (firm-years) } \\
R \text {-square } \\
\text { Hausman test }\end{array}$ & & 2 df.) \\
\hline $\begin{array}{c}\text { Variance components } \\
\text { Firm } \\
\text { Time series } \\
\text { Error }\end{array}$ & & \\
\hline
\end{tabular}

$\dagger, *, * *$ and $* * *$ are $10 \%, 5 \%, 1 \%$ and $0.1 \%$ level of significance, respectively 